\title{
ELABORATION OF ECONOMIC AND MATHEMATICAL MODEL COMPETITIVENESS MANAGEMENT OF A CONSTRUCTION ENTERPRISE
}

\author{
Ya.D. Gelrud', gelrud@mail.ru, \\ E.A. Ugryumov ${ }^{1}$, eugene74@mail.ru, \\ V.L. Rybak', rybak1323@mail.ru \\ ${ }^{1}$ South Ural State University, Chelyabinsk, Russian Federation, \\ ${ }^{2}$ Financial University under the Government of the Russian Federation, Moscow, \\ Russian Federation
}

\begin{abstract}
Management of the market economy requires the use of various economic and mathematical methods and models. The modeling method is the most important universal method of investigation. The model, as a rule, differs from the object of research, but certainly has a similarity, similar to this object, primarily with respect to those characteristics that are subject to study and forecasting.

The model of a complex system is also a system that has a physical embodiment, or written with mathematical notation, numbers, words, graphic images, and so on.

Thus, the model is a physical or sign system similar to the system under investigation with respect to the functional and structural characteristics that are the subject of the study.

There are various economic and mathematical models that are used in scientific research. The most common are the models of correlation-regression analysis, production functions and systems of econometric equations. As a rule, modern research in the field of economics and management is focused on the use of a single tool for data analysis. This article will consistently apply all of these models, which allows you to conduct the most complete and objective analysis of the mutual impact of production performance of a construction company. The article proposes an economic and mathematical model of competitiveness management of a construction enterprise based on the compilation of a system of recursive econometric equations. Formulas for calculating the endogenous and exogenous variables participating in the model are given. The calculation of the main performance indicators of the construction company is made. Proceeding from the constructed model and based on the methodology of multicriteria optimization, the authors determined the optimal indices of the production activity of the construction enterprise taking into account the given limitations. The authors analyze in detail the obtained results of calculations and convincingly proves the relevance of the methodology proposed in the article.

Keywords: economic and mathematical model, recursive equation, system, optimization, management, econometrics, production function.
\end{abstract}

\section{Introduction}

In science and practice, various mathematical methods are used to solve diverse problems that cover analysis, planning and management in all sectors of the country's economy.

Management is a conscious influence of a person on objects, processes and on the people participating in them, which is carried out in order to give a certain focus to economic activity and obtain the desired results. Control methods are defined by the ways in which the subject of management affects the control object.

Management of the market economy requires the use of various economic and mathematical methods and models. The modeling method is the most important universal method of investigation. Applying it, one should remember the concept of "analogy". The model, as a rule, differs from the object of research, but certainly has a similarity, similar to this object, primarily with respect to those characteristics that are subject to study and forecasting.

The model of a complex system is also a system (and often very complex) that has a physical embodiment, or written with mathematical notation, numbers, words, graphic images, and so on.

Thus, the model is a physical or sign system similar to the system under investigation with respect to the functional and structural characteristics that are the subject of the study. 


\section{Краткие сообщения}

There are various economic and mathematical models that are used in scientific research. The most common are the models of correlation-regression analysis, production functions and systems of econometric equations. As a rule, modern research in the field of economics and management is focused on the use of a single tool for data analysis. This article will consistently apply all of these models, which allows you to conduct the most complete and objective analysis of the mutual impact of production performance of a construction company.

\section{Economic and mathematical model of competitiveness management of a construction enterprise}

With reference to the building enterprises we will use models of correlation-regression analysis, production functions and systems of econometric equations. The most promising economic-mathematical model from the point of view of further research is the system of recursive econometric equations.

In connection with the complexity and multifaceted relationships in the construction industry, the objects of analysis and management, as well as the specifics of the specific production structure or specific objectives and forms of research, we will represent the corresponding production functions in the form of a system of equations of the following kind [1]:

$$
\left\{\begin{array}{l}
y_{1, t}=f_{1}\left(x_{3, t}, x_{2, t-1}, \ldots, z_{1, t}\right) \\
y_{2, t}=f_{2}\left(x_{1, t}, x_{3, t-1}, \ldots, z_{2, t}\right) \\
y_{3, t}=f_{3}\left(x_{2, t}, x_{1, t-1}, \ldots, z_{3, t}\right)
\end{array}\right.
$$

In this system there are three groups of variables:

1) the endogenous variables $x_{1, t}, x_{2, t}, x_{3, t}$, for the determination of which a solution of the reduced system of equations is required;

2) delayed (lagged) endogenous variables $x_{1, t-1}, x_{2, t-1}, x_{3, t-1}$, for $t$-th period they are known and determined on the basis of statistical information or as a result of solving a similar system of equations for the $(t-1)$-th period;

3 ) the exogenous variables $z_{1, t}, z_{2, t}, z_{3, t}$ are determined outside of the given system of equations.

Variables of the second and third groups are united by the fact that their values are determined by external factors with respect to the system of equations; influencing the variables of the $t$-th period, they themselves are not subjected to their inverse influence. The variables of the second and third groups are predefined. The number of these variables in the equations can seriously affect the solution of the entire system of equations.

This type of system of equations is recursive [2,3]. Equations in them are solved consistently, and not simultaneously. The first equation is solved $x_{1, t}$ is calculated as a function of only predefined variables. Then from the second equation we define $x_{2, t}$ as a function of predefined variables and already computed $x_{1, t}$. Further from the third equation, calculate $x_{3, t}$. In this case, the calculation of the first two equations is, in fact, the preparatory stage for the solution of the third equation, in which the variable $x_{3, t}$, is ultimately considered as a complex function of all other variables of the system.

As a basis for constructing an economic and mathematical model of competitiveness management of construction enterprises, it is proposed to use the following system of equations (formulas for calculating variables are given in Table 1) [4]:

$$
\left\{\begin{array}{l}
y_{1, t}=a_{11} x_{1, t}+a_{12} x_{2, t-1}+c_{1} t+\ldots+a_{1 m} x_{m, t}+\ldots+\varepsilon_{1, t} \\
y_{2, t}=b_{21} y_{1, t}+a_{21} x_{1, t-1}+a_{22} x_{2, t}+c_{2} t+\ldots+a_{2 m} x_{m, t}+\ldots+\varepsilon_{2, t} \\
y_{3, t}=b_{31} y_{1, t}+b_{32} y_{2, t}+a_{31} x_{3, t-1}+a_{32} x_{2, t}+c_{3} t+\ldots+a_{3 m} x_{m, t}+\ldots+\varepsilon_{3, t},
\end{array}\right.
$$

where

$y_{1, t}$ is quality of production at $t$ period;

$y_{2, t}$ is timeliness of performance at $t$ period; 
$y_{3, t}$ is product cost at $t$ period;

$x_{1, t}$ is profitability of production at $t$ period;

$x_{2, t}$ is a relative number of senior executives of the enterprise at $t$ period;

$x_{2, t-1}$ is a relative number of senior executives of the enterprise at $t-1$ period (lagged variable $x_{2, t}$ );

$x_{3, t}$ is workforce productivity at $t$ period;

$x_{3, t-1}$ is workforce productivity at $t-1$ period t (lagged variable $x_{3, t}$ );

$x_{4, t}$ is mechanization level (a technological level of building machines and equipment) at $t$ period;

$x_{5, t}$ is discretization of use of resources at $t$ period.

Thus, the work completion time depends on the required level of quality, and the cost depends both on quality and on the work completion time.

Calculation formulas of variables

Table 1

\begin{tabular}{|c|c|c|c|}
\hline No. & Name of variable & Calculation formula & Determination of formula \\
\hline 1 & Workforce productivity & $W=\frac{W}{N}$ & $\begin{array}{l}W \text { - scope of work in unit time; } \\
N \text { - number of employees }\end{array}$ \\
\hline 2 & Product profitability & $P_{p r}=\frac{S p}{C} \cdot 100 \%$ & $\begin{array}{l}S p \text { - sales profit; } \\
C \text { - full cost }\end{array}$ \\
\hline 3 & $\begin{array}{l}\text { Mechanization level } \\
\text { (a technological level } \\
\text { of building machines } \\
\text { and equipment) }\end{array}$ & $M=\frac{Q_{\text {mech }}}{N}$ & $\begin{array}{l}Q_{\text {mech }} \text { - scope of work made } \\
\text { by mechanical means; } \\
N \text { - total number of employees } \\
\text { at the enterprise }\end{array}$ \\
\hline 4 & $\begin{array}{l}\text { Relative number of senior } \\
\text { executives of the enterprise }\end{array}$ & $R N_{e x}=\frac{N_{e x}}{N}$ & $\begin{array}{l}N_{e x}-\text { number of senior executives } \\
\text { of the enterprise; } \\
N \text { - total number of employees } \\
\text { at the enter-prise }\end{array}$ \\
\hline 5 & Timeliness of performance & $\operatorname{Tperf}_{p r}=1-\frac{\left|T_{p l i}-T_{f i}\right|}{T_{p l i}}$ & $\begin{array}{l}T_{p l i}, T_{f i}-\text { planned and factual work } \\
\text { completion time at an } i \text { object, days }\end{array}$ \\
\hline 6 & $\begin{array}{l}\text { Discretization of use } \\
\text { of resources }\end{array}$ & $D_{r e s}=\frac{T_{d i s}}{T}$ & $\begin{array}{l}T_{d i s}-\text { time of discrete use of resources } \\
\text { at an object; } T \text { - total period of use } \\
\text { of resources }\end{array}$ \\
\hline 7 & Product cost & $C_{p r}=\frac{V S}{V} \cdot \frac{1}{P r_{a v}}$ & $\begin{array}{l}V S-\text { volume of sales in monetary } \\
\text { terms; } \\
V \text { - total volume of work; } \\
P r_{a v} \text { - an average price of } 1 \text { sq.m. of } \\
\text { apartment at local property market }\end{array}$ \\
\hline 8 & Product quality & $Q_{p r}=1-\frac{U D+W R}{S}$ & $\begin{array}{l}U D \text { - cost of ultimately defective goods; } \\
W R \text { - costs of removal faults and hidden } \\
\text { defects on the products made earlier, i.e. } \\
\text { costs of carrying out warranty repair }\end{array}$ \\
\hline
\end{tabular}

Proceeding from the constructed model and based on the Pareto [5] multicriteria optimization method, construction organizations with the best performance indicators are selected:

$$
\left\{\begin{array}{l}
y_{1, t} \rightarrow \max \\
y_{2, t} \rightarrow \max \\
y_{3, t} \rightarrow \min .
\end{array}\right.
$$




\section{Краткие сообщения}

Limitations for this system of equations are:

$$
\left\{\begin{array}{l}
x_{1, t}>0.1 \\
0<x_{2, t}<0.15 \\
0<x_{3, t} \\
0<x_{4, t} \leq x_{3, t} \\
0<x_{5, t}<0.5
\end{array}\right.
$$

In our opinion, this model allows the most objective and fully reflects the competitiveness of construction companies in current market conditions.

To solve the problem, we can use the algorithm for successive improvement of the plan (the method of successive concessions), at which the maximum is $y_{1, t}\left(y_{1}^{*}\right)$ for the given constraints on $y_{2, t}$ and $y_{3, t}$, then we find the maximum $y_{2, t}\left(y_{2}^{*}\right)$ for a given restriction to $y_{3, t}$ and $y_{1, t}>y_{1}^{*}-\Delta_{1}$, and then we find the maximum $y_{3, t}\left(y_{3}^{*}\right)$ for given constraints on $y_{1, t}>y_{1}^{*}-\Delta_{1}$ and $y_{2, t}>y_{2}^{*}-\Delta_{2}$. Here $\Delta_{i}$ is a concession determined by experts for each $i$-th indicator.

On the basis of the initial data obtained from construction enterprises, the coefficients of $x_{i, t}$ were obtained by the methods of correlation regression analysis [6] and a system of equations was compiled:

$$
\left\{\begin{array}{l}
y_{1, t}=0.003+0.218 x_{1, t}+0.03 x_{2, t}-0.0006 x_{3, t}-2.919 x_{4, t}+1.434 x_{5, t} \\
y_{2, t}=0.009+0.561 x_{1, t}+0.076 x_{2, t-1}-0.0015 x_{3, t-1}-7.4 x_{4, t}+3.567 x_{5, t} \\
y_{3, t}=-0.02-1.24 x_{1, t}-0.168 x_{2, t-1}+0.004 x_{3, t-1}+16.378 x_{4, t}-7.936 x_{5, t}
\end{array}\right.
$$

To solve this system of equations, use the Microsoft Excel "Find Solution" tool [7]. At the first stage we optimize the first objective function - product quality:

$$
y_{1, t}=0.003+0.218 x_{1, t}+0.03 x_{2, t}-0.0006 x_{3, t}-2.919 x_{4, t}+1.434 x_{5, t} \rightarrow \max .
$$

\begin{tabular}{|c|c|c|c|c|c|c|c|c|c|}
\hline 4 & A & B & C & D & $E$ & $F$ & G & $\mathrm{H}$ & I \\
\hline 1 & $\mathrm{x} 1$ & $\mathrm{x} 2$ & x3 & $\mathrm{x} 4$ & $x 5$ & & & & \\
\hline 2 & 0,23715 & \begin{tabular}{|l|l|}
0,14911 \\
\end{tabular} & 0,29875 & $\mid 0,15578$ & $\mid$\begin{tabular}{||c|}
0,45568 \\
\end{tabular} & & & & \\
\hline 3 & 1 & 0 & 0 & 0 & 0 & 0,23715 & $>=$ & 0,1 & \\
\hline 4 & 0 & 1 & 0 & 0 & 0 & 0,14911 & $>=$ & $0 \mid$ & \\
\hline 5 & 0 & 1 & 0 & 0 & 0 & 0,14911 & $<=$ & 0,15 & \\
\hline 6 & 0 & 0 & 1 & 0 & 0 & 0,29875 & $>=$ & 0 & \\
\hline 7 & 0 & 0 & 1 & -1 & 0 & 0,14297 & $>=$ & 0 & \\
\hline 8 & 0 & 0 & 0 & 0 & 1 & 0,45568 & $>=$ & 0 & \\
\hline 9 & 0 & 0 & 0 & 0 & 1 & 0,45568 & $<=$ & 0,5 & \\
\hline 10 & Objective & function & & & & & & & \\
\hline 11 & 0,218 & 0,03 & $-0,0006$ & $-2,919$ & 1,434 & $=$ & 0,82832 & & \\
\hline 12 & & & & & & & & & \\
\hline
\end{tabular}

As a result of the calculation, we get $\max y_{1, t}=y_{1, t}^{*}$. In Fig. 1 shows the results of calculations in the first stage of optimization.

Fig. 1. The first stage of optimization

Thus, the calculated maximum value of the quality level for given values of $x_{i, t}$ is $\max y_{1, t}=y_{1, t}^{*}=0.82832 \approx 83 \%$. The closer this indicator is to the unit, the higher the level of product 
quality. Such a high value of the quality index speaks about the insignificant cost of the final marriage and the costs of eliminating imperfections, as well as the costs of guarantee repairs.

At the second stage, the second objective function is optimized - the timeliness of the work:

$y_{2, t}=0.009+0.561 x_{1, t}+0.076 x_{2, t-1}-0.0015 x_{3, t-1}-7.4 x_{4, t}+3.567 x_{5, t} \rightarrow \max$.

The result of the calculation is the definition of $\max y_{2, t}=y_{2, t}^{*}$.

At the same time, the amount of assignment for $y_{1, t}$ of the indicator - product quality, is: $\Delta_{1}=0.001$. At this stage, the previous function can be degraded by no more than $\Delta_{1}=0.001$. That is, one more restriction is introduced $y_{1, t}<y_{1, t}^{*}-\Delta_{1}\left(y_{1, t}<0.82732\right)$.

As a result of the calculation, we get $\max y_{2, t}=y_{2, t}^{*}$. In Fig. 2 shows the results of calculations in the second stage of optimization.

\begin{tabular}{|c|c|c|c|c|c|c|c|c|c|c|}
\hline 4 & A & B & C & D & $\mathrm{E}$ & $\mathrm{F}$ & G & H & I & J \\
\hline 1 & x1 & x2 & x3 & x4 & $\times 5$ & y1 & & & & \\
\hline 2 & 0,21897 & 0,13524 & 0,35687 & 0,11257 & \begin{tabular}{|l|}
0,42114 \\
\end{tabular} & 0,79754 & 0,79754 & $4<=$ & 0,82732 & \\
\hline 3 & 1 & 0 & 0 & 0 & 0 & 0 & 0,21897 & $7>=$ & 0,1 & \\
\hline 4 & 0 & 1 & 0 & 0 & 0 & 0 & 0,13524 & $4>=$ & 0 & \\
\hline 5 & 0 & 1 & 0 & 0 & 0 & 0 & 0,13524 & $4<=$ & 0,15 & \\
\hline 6 & 0 & 0 & 1 & 0 & 0 & 0 & 0,35687 & $7>=$ & 0 & \\
\hline 7 & 0 & 0 & 1 & -1 & 0 & 0 & 0,2443 & $3>=$ & 0 & \\
\hline 8 & 0 & 0 & 0 & 0 & 1 & 0 & 0,42114 & $4>=$ & 0 & \\
\hline 9 & 0 & $\underline{0}$ & 0 & $\underline{0}$. & 1 & 0 & 0,42114 & $4<=$ & 0,5 & \\
\hline 10 & Objective & function & & & & & & & & \\
\hline 11 & 0,218 & 0,03 & $-0,0006$ & $-2,919$ & 1,434 & & $=$ & 0,79754 & & \\
\hline 12 & 0,561 & 0,076 & $-0,0015$ & $-7,4$ & 3,567 & & $=$ & 0,80177 & & \\
\hline 13 & & & & & & & & & & \\
\hline 14 & & & & & & & & & & \\
\hline
\end{tabular}

Fig. 2. The second stage of optimization

That is, the maximum value of the level of timeliness of the work for given values of $x_{i, t}$ is $\max y_{2, t}=y_{2, t}^{*}=0.80177 \approx 81 \%$. Ideal is the value equal to 1 . It can be achieved when the planned and actual production times for the $i$-th facility are completely the same. In our case, the value of the timeliness of the work is at a sufficiently high level, taking into account the additional constraint $\left(y_{1, t}<0.82732\right)$, introduced after the first stage of optimization.

At the third stage, the third objective function is optimized: the cost of production:

$$
y_{3, t}=-0.02-1.24 x_{1, t}-0.168 x_{2, t-1}+0.004 x_{3, t-1}+16.378 x_{4, t}-7.936 x_{5, t} \rightarrow \min .
$$

As a result of the calculation, we get $\min y_{3, t}=y_{3, t}^{*}$.

At the same time, the amount of assignment for $y_{2, t}$ of the indicator - timeliness of work performance, is: $\Delta_{2}=0.01$ At this stage, the previous function can be degraded by no more than $\Delta_{2}=0.01$. That is, another restriction is introduced $y_{2, t}<y_{2, t}^{*}-\Delta_{1} \quad\left(y_{2, t}<0.79177\right)$.

Thus, the final calculation is as follows (Fig. 3). 


\section{Краткие сообщения}

\begin{tabular}{|c|c|c|c|c|c|c|c|c|c|c|c|}
\hline 4 & A & B & C & D & $\mathrm{E}$ & $\mathrm{F}$ & G & H & I & $J$ & K \\
\hline 1 & $\mathrm{x} 1$ & $\times 2$ & $\times 3$ & $\mathrm{x} 4$ & $\times 5$ & $\mathrm{y} 1$ & $\mathrm{y} 2$ & & & & \\
\hline 2 & 0,22471 & 0,14112 & 0,32214 & 0,13129 & 0,48213 & 1 & 0 & 0,54572 & $<=$ & 0,79654 & \\
\hline 3 & & & & & & 0 & 1 & 0,65857 & $\leq$ & 0,79177 & \\
\hline 4 & 1 & 0 & 0 & 0 & 0 & 0 & 0 & 0,22471 & $>=$ & 0,1 & \\
\hline 5 & 0 & 1 & 0 & 0 & 0 & 0 & 0 & 0,14112 & $>=$ & 0 & \\
\hline 6 & 0 & 1 & 0 & 0 & 0 & 0 & 0 & 0,14112 & $<=$ & 0,15 & \\
\hline 7 & 0 & 0 & 1 & 0 & 0 & 0 & 0 & 0,32214 & $>=$ & 0 & \\
\hline 8 & 0 & 0 & 1 & -1 & 0 & 0 & 0 & 0,19085 & $>=$ & 0 & \\
\hline 9 & 0 & 0 & 0 & 0 & 1 & 0 & 0 & 0,48213 & $>=$ & 0 & \\
\hline 10 & 0 & 0 & 0 & $\underline{0}$ & 1 & 0 & 0 & 0,48213 & $\leq=$ & 0,5 & \\
\hline 11 & Objective & function & & & & & & & & & \\
\hline 12 & 0,218 & 0,03 & $-0,0006$ & $-2,919$ & 1,434 & & & $=$ & 0,54572 & & \\
\hline 13 & 0,561 & 0,076 & $-0,0015$ & $-7,4$ & 3,567 & & & $=$ & 0,65857 & & \\
\hline 14 & $-1,24$ & $-0,168$ & 0,004 & 16,378 & $-7,936$ & & & $=$ & 0,97217 & & \\
\hline 15 & & & & & & & & & & & \\
\hline
\end{tabular}

Fig. 3. The third stage of optimization

The final stage of the optimization process is the determination of the minimum value of the product cost index. In this study, the value of the product cost index was found to be $\min y_{3, t}=y_{3, t}^{*}=0.97217 \approx 97 \%$. This is the main indicator characterizing the competitiveness of the construction enterprise and its "viability", "survival" in the market. If $y_{3, t}^{*}>1$, this means that the value of the enterprise's products is above the market average, hence, the enterprise's products are not competitive, and the enterprise needs to revise its pricing policy. On the other hand, if this indicator is too low, then there are risks of deterioration of the financial condition of the enterprise, which can lead to withdrawal from the market or even bankruptcy. In our case, the cost indicator is $97 \%$. This indicates the conformity of the cost of production to the current market conditions and at the same time the activity of the enterprise remains quite profitable.

\section{Conclusion}

Thus, an economic and mathematical model for managing the competitiveness of a construction enterprise has been developed. This model is based on three interrelated basic indicators of competitiveness (product quality, timeliness of work performance and product cost), combined in a system of recursive econometric equations. At the same time, the timeliness of performance depends on the required level of product quality, and the cost of production depends on the required level of product quality, and on the timeliness of the work.

Summarizing this study, it should be noted that the optimal indicators of production activity were obtained that allow construction companies to determine for themselves the most promising directions of development, to identify their strengths and weaknesses, to promote the development and adoption of sound strategically correct management decisions, which ultimately leads to increase competitiveness.

\section{References}

1. Gelrud Y.D. Metody issledovaniya v menedzhmente. Uchebnoye posobiye. [Research Methods in the Management. Teach. Med.]. Chelyabinsk, South Ural St. Univ. Publ., 2014. 282 p.

2. Litvak B.G. Ekspertnaya informatsiya: metody polucheniya $i$ analiza. [Expert Information: Methods of Receiving and Analysis]. Moscow, Radio and Communication, 2008. 184 p.

3. Popov A.M., Sotnikov V.N. Ekonomiko-matematicheskiye metody i modeli. Vysshaya matematika dlya ekonomistov. Uchebnik dlya vysshikh uchebnykh zavedeniy po spetsial'nostyam ekonomiki $i$ upravleniya [Economic and Mathematical Methods and Models. Higher Mathematics for Economists. Textbook for Higher Education Institutions on Specialties of Economy and Management]. Second ed., revised and enlarged. Moscow, Yurayt Publ., 2012. 479 p. 
4. Gusev E.V., Ugryumov E.A., Shepelev I.G. [Organizational and Economic Bases of Competitiveness of Construction Enterprises]. Bulletin of the South Ural State University. Ser. Economics and Management, 2013, vol. 7, no. 1. (in Russ.)

5. Klimov G.P. Teoriya veroyatnostey i matematicheskaya statistika. [Theory of Probability and Mathematical Statistics]. Moscow, MSU, 2011.368 p.

6. Ugryumov E.A., Shindina T.A. [Intellectual Data Analysis of Production Profitability Influence on the Competitiveness of Construction Enterprises]. Journal of Applied Economic Sciences, 2016, vol. XI, no. 8 (46). (in Russ.)

7. Eliseeva I.I. (Ed.) Ekonometrika: uchebnik dlya magistrov [Econometrics: a Textbook for Masters]. Moscow, Yurayt Publ., 2014. 453 p. Series: Master.

Received 20 April 2018

\title{
РАЗРАБОТКА ЭКОНОМИКО-МАТЕМАТИЧЕСКОЙ МОДЕЛИ УПРАВЛЕНИЯ КОНКУРЕНТОСПОСОБНОСТЬЮ СТРОИТЕЛЬНОГО ПРЕДПРИЯТИЯ
}

\author{
Я.Д. Гельруд", Е.А. Угрюмов ${ }^{1}$, В.Л. Рыбак ${ }^{2}$ \\ ${ }_{1}^{1}$ Южно-Уральский государственный университет, г. Челябинск, Россия, \\ ${ }^{2}$ Финансовый университет при Правительстве Российской Федерации, г. Москва, \\ Россия
}

Управление рыночной экономикой требует использования различных экономических и математических методов и моделей. Метод моделирования является наиболее важным универсальным методом исследования. Модель, как правило, отличается от объекта исследования, но, безусловно, имеет сходство, подобное этому объекту, прежде всего в отношении тех характеристик, которые подлежат изучению и прогнозированию.

Модель сложной системы также является системой, которая имеет физическое воплощение или написана математическими обозначениями, числами, словами, графическими изображениями и т. д.

Таким образом, модель представляет собой физическую или сигнальную систему, подобную системе, исследуемой в отношении функциональных и структурных характеристик, которые являются предметом исследования.

Существуют различные экономические и математические модели, которые используются в научных исследованиях. Наиболее распространенными являются модели корреляционнорегрессионного анализа, производственные функции и системы эконометрических уравнений. Как правило, современные исследования в области экономики и управления ориентированы на использование единого инструмента для анализа данных. В этой статье будут последовательно применяться все эти модели, которые позволят провести наиболее полный и объективный анализ взаимного влияния производственных показателей строительной компании. В статье предлагается экономико-математическая модель управления конкурентоспособностью строительного предприятия на основе составления системы рекурсивных эконометрических уравнений. Приведены формулы для расчета эндогенных и экзогенных переменных, участвующих в модели. Произведен расчет основных показателей деятельности строительного предприятия. Исходя из построенной модели и основываясь на методике многокритериальной оптимизации, авторами определены оптимальные показатели производственной деятельности строительного предприятия с учетом заданных ограничений. Авторы детально анализируют полученные результаты расчетов и убедительно доказывают актуальность предложенной в статье методики.

Ключевые слова: экономико-математическая модель, рекурсивное уравнение, оптимизация, управление, система, эконометрика, производственная функиия. 
Литература

1. Гельруд, Я.Д. Методы исследования в менеджменте: учеб. пособие / Я.Д. Гельруд. - Челябинск: Издат. иентр ЮУрГУ, 2014. - 282 с.

2. Литвак, Б.Г. Экспертная информация: методы получения и анализа / Б.Г. Литвак. - М.: Радио и связь, 2008. - 184 с.

3. Попов, А.М. Экономико-математические методы и модели. Высшая математика для экономистов: учеб. для высш. учеб. заведений по специальностям экономики и управления / А.М. Попов, В.Н. Сотников; под ред. А.М. Попова. - второе изд., пересмотр. и расшир. - М.: Юрайm, 2012. $-479 c$.

4. Гусев, Е.В. Организаиионно-экономические основы конкурентоспособности строительных предприятий / Е.В. Гусев, Е.А. Угрюмов, И.Г. Шепелев // Вестник ЮУрГУ. Серия «Экономика и менеджмент». - 2013. - T. 7, № 1 .

5. Климов, Г.П. Теория вероятностей и математическая статистика / Г.П. Климов. - М.: МГУ, 2011. $-368 c$.

6. Угрюмов, Е.А. Интеллектуальный анализ данных о влиянии рентабельности производства на конкурентоспособность строительных предприятий / Е.А. Угрюмов, Т.А. Шиндина // Журнал прикладных экономических наук. - 2016. - T. XI, № 8 (46).

7. Эконометрика: учеб. для магистров / И. И. Елисеева [и др.]; под ред. И.И. Елисеевой. - М.: Юрайт, 2014. - 453 c. - (Серия: Магистр).

Гельруд Яков Давидович, д-р техн. наук, профессор кафедры информационно-аналитического обеспечения управления в социально-экономических системах, Южно-Уральский государственный университет, г. Челябинск; gelrud@mail.ru.

Угрюмов Евгений Александрович, старший преподаватель кафедры экономики и управления на предприятиях строительства и землеустройства, Южно-Уральский государственный университет, г. Челябинск; eugene74@mail.ru.

Рыбак Вадим Львович, студент-бакалавр 4 курса, Финансовый университет при Правительстве Российской Федерации, г. Москва; rybak1323@mail.ru.

Поступила в редакцию 20 апреля 20182.

\section{ОБРАЗЕЦ ЦИТИРОВАНИЯ}

Gelrud, Ya.D. Elaboration of Economic and Mathematical Model Competitiveness Management of a Construction Enterprise / Ya.D. Gelrud, E.A. Ugryumov, V.L. Rybak // Вестник ЮУрГУ. Серия «Компьютерные технологии, управление, радиоэлектроника». - 2018. T. 18, № 3. - C. 157-164. DOI: $10.14529 /$ ctcr 180317

\section{FOR CITATION}

Gelrud Ya.D., Ugryumov E.A., Rybak V.L. Elaboration of Economic and Mathematical Model Competitiveness Management of a Construction Enterprise. Bulletin of the South Ural State University. Ser. Computer Technologies, Automatic Control, Radio Electronics, 2018, vol. 18 , no. 3, pp. 157-164. DOI: 10.14529/ctcr180317 